NBSIR 82-2525

\title{
An Assessment of Correlations Between Laboratory and Full-Scale Experiments for the FAA Aircraft Fire Safety Program, Part 4: Flammability Tests
}

U.S. DEPARTMENT OF COMMERCE

National Bureau of Standards

National Engineering Laboratory

Center for Fire Research

Washington, DC 20234

July 1982

Sponsored by:

U.S. Department of Transportation

Federal Aviation Administration

Technical Center

Atlantic City Airport, NJ 08405 



\section{AN ASSESSMENT OF CORRELATIONS BETWEEN LABORATORY AND FULL-SCALE EXPERIMENTS FOR THE FAA AIRCRAFT FIRE SAFETY PROGRAM, PART 4: FLAMMABILITY TESTS}

James G. Quintiere

U.S. DEPARTMENT OF COMMERCE

National Bureau of Standards

National Engineering Laboratory

Center for Fire Research

Washington, DC 20234

July 1982

Sponsored by:

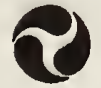

U.S. Department of Transportation

Federal Aviation Administration

Technical Center

Atlantic City Airport, NJ 08405

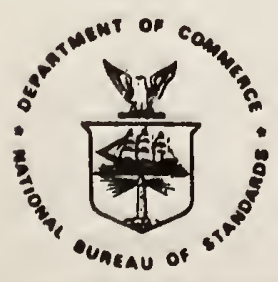

U.S. DEPARTMENT OF COMMERCE, Malcolm Baldrige, Secretary NATIONAL BUREAU OF STANDARDS. Ernest Ambler, Director 


$$
\therefore-1+\cdots
$$




\title{
An Assessment of Correlations Between Laboratory and Full-Scale Experiments For the FAA Aircraft Fire Safety Program, \\ Part 4: Flammability Tests
}

by

James Quintiere

\begin{abstract}
A review is made of studies in which full-scale fire growth was compared with laboratory test data on materials. Both room and corridor fires are included in which primarily interior lining materials have been the combustible element. The studies include standard test methods and other laboratory devices used in the United States and other countries. An effort was made to intercompare experimental results in a common basis. For example, maximum room temperature data are compared with ASTM E-84 flame spread classifications for several full-scale tests which involved nearly the same room geometries and same fuel arrangements.
\end{abstract}

Keywords: Compartment fires, correlations, fire growth, flammability tests, flashover 
TABLE OF CONTENTS

Page

INTRODUCTION

Purpose

1

Background

1

ANALYSIS OF RESULTS

2

CONCLUSIONS

5

REFERENCES 


\section{LIST OF ILLUSTRATIONS}

Figure

Page

1 Corner and Room Temperatures compared with ASTM E-84 Ratings

2 Maximum Room Temperatures compared with ASTM E-84

3 Maximum Room Temperatures compared with Energy Release Data

4 Incident Flux Compared with Critical Flux for Spread [15]

5 Critical Flux for Spread compared with Actual Fire Spread on Floors [13]

6 Room Temperature compared with Radiant Heat Release [23] 


\section{LIST OF TABLES}

Table

Page

1 Comparison of ASTM E-162 with Room Temperature [11]

2 Comparison of ASTM E-162 for Corridor Fire Spread [12] 10

3 Corridor Spread Compared with Early Version of BS 476 pt 1 [16] 11

4 Room Wal1 Lining Tests Compared to BS 476 pt 1 Class [17] 11

5 Corridor Wall and Ceiling Spread Compared with BS 476 Part 6 [19] 12

6 Flashover Time in 1/3-Scale Compartment Compared with $\mathrm{C}$ of Epiradiateur [21]

7 Energy Released in Aircraft Tests Compared to Laboratory Test Results [25] 


\section{ACKNOWLEDGEMENT}

This study was sponsored by the Fire Safety Branch of The Federal Aviation Administration Technical Center at Atlantic City, New Jersey. The author gratefully appreciates the advice of Mr. R. Hill, the technical monitor, and also the assistance of Mr. C. Sarkos of the FAA. 


\section{INTRODUCTION}

\section{PURPOSE}

The purpose of this review is to assess the nature of correlations between measurements by fire flammability test methods and full-scale fire results. By flammability it is meant that the concern is with fire growth, energy development and the level of temperature or time to full-involvement flashover in fires. The scope of the review was not to review all available literature, but was to be sufficiently complete in order to draw some insight into the success or limitations of these correlations. Underlying the nature of fire growth are the elements of ignition, flame spread and energy release for a material. Also the influence of scale and enclosure heat transfer effects bear on these processes. Since all of these processes are not completely understood it is understandable that fire test methods are empirical and their correlation with full-scale results will be tenuous. Nevertheless, the need to establish fire safety requirements for materials requires vigorous pursuit and examination of such correlations.

\section{BACKGROUND}

The dilemma in practice of establishing correlations is what to compare with what. This is illustrated in the study by Nicholas [1] of comparisons among fire test methods (ASTM E162, OSU rate of heat release device, vertical bunsen burner test, the limiting oxygen index test, and thermogravimetric analysis) for twenty aircraft materials. He concludes that the rank order of performance depends on the test and mostly the tests do not correlate with each other. In reviewing correlations with full-scale results, various test methods will be reported in this review. They will not be described fully and it will be assumed that the interested reader understands these tests or has access to more information on them. In many cases the tests have not been standardized or their procedures have changed in time.

Nearly all of the studies to be reported involve lining materials for walls and ceilings, and in some cases aircraft interior linings; others involve floor coverings and one study involves matresses. For the room studies, the igniting source used has been moderate in its intensity and has varied from waste containers to cribs, to gas burner diffusion flames, to radiant panels. It may be estimated that these sources provided nominally $100 \mathrm{~kW}$ at 2 to $4 \mathrm{~W} / \mathrm{cm}^{2}$ with flame heights below the ceiling. For the corridor fire studies, usually fully-involved adjoining room fires were the igniting source. Also the room and corridor configurations were of comparable size and construction in many of these tests so that intercomparisons are somewhat justified.

In general two distinct parameters could and have been used to evaluate the fire growth characteristics in full-scale experiments. One parameter is the maximum gas temperature reached in the experiment. The other is the time to reach flashover conditions which could correspond to a temperature level of 500 to $600^{\circ} \mathrm{C}$. Other parameters have been considered, such as heat 
flux, time for ignition, or time for flames to extend from the room; but the temperature and flashover time appear to be the most significant. These parameters will be prevalent in the analyses to follow.

\section{ANALYSIS OF RESULTS}

An analysis of interior finish fires for a number of materials and configurations was carried out by Underwriters Laboratories Inc. [2]. They considered walls alone, corners with a ceiling, rooms and corridors. Their ignition sources ranged from $1 \mathrm{~kg}$ waste containers to $23 \mathrm{~kg}$ wood cribs. They developed data from laboratory test methods which included ASTM E-84 (FSC), ASTM E-162 ( $\mathrm{I}_{\mathrm{S}}$ ), and the OSU and NBS calorimeter devices. A representative comparison of the results for the corner and room configurations is shown in Figure 1 in terms of maximum gas temperature and E-84 FSC value. The selection of the thermocouple position to represent a characteristic temperature does influence the results. In particular, the two "low" temperatures for the corner results at FSC 155 and 360 would be higher using a thermocouple position at the center of the ceiling. This selection issue is, of course, present in all of these comparisons and can not be easily resolved. Excluding these two low temperature data points, the corner results offer a reasonable correlation but the room results do not.

A more extensive review of ASTM E-84 performance in correlating room fire results has been presented by Parker [3]. Drawing on those assembled resuits, which include the UL data [2], and results by Fang [4], Budnick [5,6] and Beitel et al [7], gives the plot in Figure 2. Since all these room configurations and ignition sources were similar it is justified to plot the results as shown. That is, the primary source of energy release contributing to the room temperature is a function of the lining material, and the effects of ignition source and room configuration are expected to be less important for these data. In fact, the contribution of the ignition source appears to be roughly $150^{\circ} \mathrm{C}$ based on the intercept in Figure 2. With the exception of the low density foam data designated, a general corralation of E-84 FSC with temperature is apparent.

Another view of essentially this same data set for lining materials along with the inatiress fire results of Babrauskas [8] is presented in Figure 3 in terms of energy release rates per unit area. These data were derived from the NBS calorimeter devices at the irradiance levels indicated. Although they depend on irradiance and time, these variations might be considered small compared to the range of results possible for different materials. In the mattress study by Babrauskas [8], a three-minute average value for energy release rate was adopted and those values are plotted in Figure 3 . Peak values of heat release rate were considerably higher and do not correlate as well with temperature. Despite these effects of time, a correlation

appears reasonable except for some low density foam materials in the UL [2] and NRC [3] studies. It is known that room temperature is directly dependent on the total rate of energy release (for similar room configurations). Hence, a correlation with rate of energy release per unit area is only explainable if the rate of spread is related to this rate per unit area. For wind-aided or upward fire spread, the energy release per unit area does control the rate 
of spread along with other factors such as the density of the material. Lack of accounting for al1 of these spread factors, in particular density, does suggest the reason for an incomplete correlation in Figure 3 .

Other studies related to ASTM E-84 were done by Christian and Waterman [9] for corridor wall and ceiling linings, and by D'Souza and McGuire [10] for half and full-scale corner-canopy tests. The first study found the times to achieve extensive spread was inversely dependent on both the E-84 FSC value and on initial fire intensity, the ignition source. The FSC values did not rank order exactly with inverse time. The second study found that E-84 FSC did not correlate with Inverse time of celling flaming, but a modified E-84 index based on average spread velocity in the E-84 tunnel did correlate. This study involved foamed plastics and their potential for high spread rate needs to be considered in explaining their fire growth behavior in rooms.

Limited results are available for the ASTM E-162 radiant panel test (index $=I_{s}$ ). Williamson [11] tested candidate lining materials for rapid transit vehicles. These results are shown in Table 1 for two igniting sources. Clearly the results depend on the ignition source, and the data are too sparse to comment on an overall correlation potential for E-162. Other work by Mcfuire [12] for corridor wall, floor and ceiling materials initiated by a room fire is presented in Table 2 . These results strongly suggest that combustible walls are more critical than, perhaps ceilings, and definitely floors, in terms of fire growth potential. For these elements alone, $I_{S}=35$ for walls led to extensive spread, while an $I_{S}>130$ for a ceiling and an $\mathrm{I}_{S}>435$ for a floor appears necessary for extensive spread.

An extensive study by NBS of floor covering fire spread in corrldors led to a radiant panel test method for floor coverings (ASTM E-648 or NFPA 253 [13]). It was apparent in that study that a complete correlation between the NBS corridor tests and a variety of laboratory and standard test method results for the floor covering materials did not exist [14]. It was clear, however, that radiant heating was a significant factor in promoting floor covering spread. Consequently, a test was established which measured the minimum radiant heat flux necessary to sustain flame spread. A demonstration of the applicability of this test result to full-scale data is illustrated in Figure 4 and [15]. The measured (and calculated) heat flux is shown for a point on the corridor floor $1.2 \mathrm{~m}$ from the doorway of the room fire. For material 346, this flux did not ever exceed its "critical" flux to sustain flame spread. Yet for the two other materials, 348 and 349 , the critical flux was exceeded and rapid and complete spread resulted in the corridor. Thus, this critical flux gives an indication of whether spread will continue, but no indication of its rate or intensity if it is exceeded due to the intensity level of the igniting fire. A more dramatic view of that point is shown in Figure 5 taken from the commentary on NFPA 253 [13]. There, a low critical flux tends to correspond with significant fire spread more than high critical flux ratings in both experimental fires and actual fire incidents; however, a high critical flux does not guarantee limited spread.

It is interesting to examine some flammability test method developments in other countries. A 1944 UK report [16] describes the development of the Surface Spread of Flame Test BS476 part 1. This test uses a vertical radiant panel with a test sample aligned normal to the panel. A classification method is based on the extent of spread and time for spread along the specimen away from the panel. Table 3 shows their results based on full-scale corridor tests with combustible wall and ceiling materials. Later results [17] are shown in Table 4 for wall linings in rooms. 
In a CIB review paper on relating flashover with fire test methods, Thomas [18] reports that model room experiments gave a range of flashover times for materials of class 1 by BS476 part 1 . These factors evidently gave rise to BS476 part 6, the British Fire Propagation test. This test has a $3.6 \mathrm{~cm}$ square sample exposed to a gas flame in a chamber in which the exhaust gas stream temperature is monitored over time. The index (I) is based on this time-temperature curve and its value above a reference temperature curve $(\Theta)$ established for a noncombustible material. Thomas [18] reports that flashover times correlated directly with the time for the test temperature to reach $\theta+50^{\circ} \mathrm{C}$ and inversely with the time the test temperature remained above $\theta+50^{\circ} \mathrm{C}$. This suggests that time to flashover is inversely proportional to total energy release and the rate of energy release; not an unreasonable result. Later, tests by Malhotra et al. [19] show in Table 5 the comparison of spread in a corridor lined with wall and ceiling materials classified by BS476 part 6 (Index $=$ I).

Another approach in correlating wall and ceiling lining spread in corridors was taken in Denmark by Malmstedt et al. [20]. They found that the time over which the corridor material was exposed to the room fire before its ignition was significant. They, thus, correlated the time integral of room temperature rise up to the time of corridor ignition $\left(t_{i g}\right)$ divided by $\sqrt{t_{i g}}$ with a laboratory test that measured the minimum radiant flux ${ }_{\text {co }}$ ignite the material after a twenty minute exposure. It can be shown [15] that their approach can be explained in terms of ignition theory.

The French use the Epiradiateur test composed of an inclined specimen exposed to a radiant heat source enclosed in a vertical chamber. Several parameters are measured and then combined to give a classification. They include data on time to ignite (I), maximum flame height (S), mean flame height (H), and the time integral of temperature rise over 20 minutes (C). Bullen [21] recently analyzed the results of Tourette [22] for correlation of the Epiradiateur with 1/3-scale wall lining compartment fires. He found that the $\mathrm{C}$ (energy parameter) factor correlated best the time to flashover. Those results are shown in Table 6.

A recent study in Australia by Moulen et al. [23] compared results of a corner-wall fire in a room with results from the test for Early Fire Hazard Properties (EFH): AS 1530 Part 3. The test method uses a radiant panel at $800^{\circ} \mathrm{C}$ to heat a vertical specimen which is moved toward it until it ignites. Radiant flux from the specimen is measured as well as the temperature at the exhaust port of the enclosure containing the components. The EFH test measures time to ignite ( $t$. ) (for the moving specimen), time (after ignition) to emit a specific flux ( $\left.t_{f}\right)$, and a two minute integration (after ignition) of the flux measured from the specimen. The $t_{f}$ represents the time to achieve significant burning (after ignition) and was found to correlate very well with the time for flames to reach the ceiling in the room tests following wall ignition. The radiant flux integral, since its taken over a fixed two minute interval, yields a measure of the rate of radiant energy release, not necessarily the total rate of energy release. These results do not correlate very well with room temperature rise. They are plotted in Figure 6 and are in contrast to those plotted in Figure 3. 
The problem of post-crash fire spread in an aircraft has stimulated some new studies of test methods and their interpretation. Work by Speith et al. [24] at McDonnell Douglas and Tustin [25] at Boeing Company comprise a similar approach. They used an aircraft fuselage section with a fixed ventilation flow rate and simulate the fire source with a large radiant panel located within the fuselage. Large sheets of aircraft lining material were then tested over a range of flux levels and distributions. The OSU calorimeter device with modifications was used to measure the energy and product release rates for these same materials. A distinct difference of this work compared to the required test for aircraft materials, namely the FAR 25. 853 Bunsen Burner Test, is the large extent of sample heated in the full-scale simulation and the attempt to predict the fullscale results from the OSU apparatus data. They demonstrate how to use the energy and product yield test data to predict (average) temperature and specie concentrations in the exhaust flow from the full-scale experiments. They achieve mixed success which suggests the approach may be sound, but the sources of error are not apparent. Tustin's [25] results comparing the total energy release in ful1scale for two fire scenarios with data from laboratory tests are shown in Table 7. The Bunsen Burner result does not correlate with the full-scale energy release, the Q (energy release factor) of ASTM E-162 is fair, and the OSU result at $2.5 \mathrm{~W} / \mathrm{cm}^{2}$ irradiance does best. Spieth et al. [24] has good success at predicting temperature with the OSU energy release data, but finds that the thermal technique for calculating energy release rate in the OSU device gives peak values that are nominally 50 per cent lower than peak values obtained through using oxygen depletion calorimetry. Hence an issue of accuracy needs to be addressed in these measurements.

\section{CONCLUSIONS}

The rate of energy release (per unit area) measured in a laboratory test apparatus seems to be the most significant parameter in correlating full-scale data on room temperature or time to flashover. This is reflected in the review presented here. The rate of energy release is not always directly measured, and even when it is, there is no a priori method for deciding how to express it in terms of time or exposure heat flux; for example, a peak value or three minute average at $3 \mathrm{~W} / \mathrm{cm}^{2}$ or $6 \mathrm{~W} / \mathrm{cm}^{2}$, etc. In some experiments it is clear, due to the nature of the materials or the test conditions, that other factors such as ignition and flame spread rate are important to achieve a full correlation. In fact in some cases, that type of insight motivated a correlation strategy. The importance of energy release rate in establishing the FSC of ASTM E- 84 has been made clear by Parker [3] so that energy release rate may be regarded as an alternative to FSC. Nevertheless without some insight and at least conceptual modeling of the fire scenario considered for correlation, a correlation strategy is purely empirical. It has no fundamental basis for success.

To develop a successful correlation, the dominant processes must be identified and dealt with in as much quantitative detail as possible and practical. For the FAA postcrash fire scenario (with no wind) these processes can be identified as follows: 
(1) Ignition (spontaneous or piloted) by radiation from the external pool fire. This would apply to the exposed materials, namely the seats and carpeting. The materials in the upper portion of the cabin would be exposed to the pulsating door flames. This flame ignition phenomenon is less defined. A response to these processes is to measure the time to ignite under heat flux levels commensurate with the external fire characteristics. This is a simple test, yet no standard test method exists for doing this.

(2) Following ignition, a distinct area of material should quickly get involved in combustion. This area, in particular for the seat configuration, could be estimated from knowledge of the radiant flux distribution due to the external pool fire and from a measurement of the minimum flux for piloted ignition ( $\dot{q}_{o} i{ }$ ). Relatively rapid spread should extend from the ignition point to the position of minimum ignition flux. This initial rate of energy release could be determined from additional measurements of energy release rate per unit area, $\dot{Q}^{\prime \prime} i \cdot e$.

$$
\dot{Q}=W \cdot \int_{0}^{x\left(\dot{q}_{0}, i g\right)} \dot{Q}^{\prime \prime} d x
$$

where $W$ is width (assume one dimensional spread as observed on the seat configurations).

(3) Subsequent spread will occur more slowly until radiant heating levels increase significantly as the cabin ceiling heats. Lateral and horizontal spread rates on the seat materials could be determined from ignition and flame spread data as outlined by Quintiere [27].

(4) Following ignition, flame spread on the upper cabin surfaces becomes a significant factor. Other than the ASTM E-84 test, no test is specifically designed to address this. It has been shown [3] that this type of spread depends on energy release rate per unit area $\dot{Q}^{\prime \prime}$ and the material properties $\mathrm{k} \rho \mathrm{c}$, as well as flame heat transfer rate. This problem has clearly not been solved. Nevertheless, an empirical manner for addressing this flame spread rate is to consider it directly proportional to $\dot{Q}^{\prime \prime}$. That is, $\dot{Q}^{\prime \prime}$ would reflect a measure of the flame spread rate for ceiling materials.

In summary, the sense of the review and its application to the post crash fire scenario suggest that rate of energy release per unit area $Q^{\prime \prime}$, ignition and flame spread characteristics, in that order, are the phenomena that should be addressed in laboratory measurements and in correlations with full-scale results. 


\section{REFERENCES}

1. Nicholas, E. B., "Evaluation of Existing Flammability Test Methods by Comparison of the Flammability Characteristics of Interior Materials," Federal Aviation Administration Report No. FAA-NA-79-46. (March 1980).

2. Castino, G. T., Beyreis, J. R. and Metes, W. S., "Flammability Studies of Cellular Plastics and Other Building Materials Used for Interior Finishes," Underwriters La. Inc. Northbrook, Illinois (1975).

3. Parker, W. J., "An Assessment of Correlations Between Laboratory and Full Scale Experiments for The FAA Aircraft Fire Safety Program, Part 1: ASTM E-84, National Bureau of Standards, NBSIR (to be published).

4. Fang, J. B., "Fire Buildup in a Room and the Role of Interior Finish Materials," National Bureau of Standards, TN 879, (1975).

5. Budnick, E. K., "Fire Spread Along a Mobile Home Corridor," Nationa1 Bureau of Standards, NBSIR 761021, (July 1976).

6. Budnick, E. K., "Mobile Home Living Room Fire Studies: The Role of Interior Finish," National Bureau of Standards NBSIR 781530, (Sept. 1978).

7. Beitel, J. J. and Herrera, W. R., "Ful1-scale Fire Tests on Specific Wall and Ceiling Materials of Mobile Home Modules," Southwest Research Institute, SWRI Proj. No. 03-4736 (Jan. 1980).

8. Babrauskas, V., "Combustion of Mattresses Exposed to Flaming Ignition Sources Part II, Bench-Scale Tests and Recommended Standard Test," National Bureau of Standards, NBSIR 80-2186 (Oct. 1980).

9. Christian, W. J. and Waterman, T. E., "Fire Behavior of Interior Finish Materials," Fire Technology, Vo1. 6, No. 3, (Aug. 1970) p 165.

10. D'Souza, M. V. and McGuire, J. H., "ASTM E-84 and the Flammability of Foamed Thermosetting Plastics," Fire Technology, Vo1. 13, No. 2, (May 1977) p 85.

11. Williamson, R. B., "Analysis of BART Fire Hardening Program, Report to BART, (April 1981).

12. McGuire, J. H., "The Spread of Fire in Corridors" Fire Technology, Vo1. 4, No. 2, (May 1968) p. 103.

13. Anonymous, "Flooring Radiant Panel Test 1978," National Fire Protection Association, NFPA 253, (1978).

14. Quintiere, J. and Huggett, C., "An Evaluation of Flame Spread Test Methods for Floor Covering Materials," National Bureau of Standards, NBS Special Publication 411, (November 1974) p. 59. 
15. Quintiere, J., "The Spread of Fire from a Compartment - A Review", Amer. Soc. for Testing and Materials, Special Technical Publication 685, (1980).

16. Anonymous, "Spread of Flames on Combustible Surfaces", Dept. of Scientific and Industrial Research, Building Res. Station, Garston, Herts. V. K. (Apri1 1944).

17. Anonymous, Fire Research 1960, Dept. of Scientific and Industrial Research Organization, London, Her Majesty's Stationery office (1961) p. 24 .

18. Thomas, F. H., "Flashover and Fire Propagation Tests", Conseil International du Batiment, Paper CIB/FRWP25/UK (1957).

19. Malhotra, H. L., Morris, W. A., and Hopkinson, J. S., "The Fire Propagation Test as a Measure of Fire Spread. Correlation with Full-scale Fires in Corridors", Fire Research Station, U. K., FR Note No. 876 (June 1971).

20. Hansen, G., Jannerup, A., Less, H. G., Hamman-Pedersen, O., Jau1, H., and Malmstedt, K., "Report on Tests Concerning Fires in Ships Corridors", Committee of Association of Danish Shipbuilders and Marine Engineers, H. Jaul, Chairman, Prindstrup (1958).

21. Bullen, M. L., "A Comparison of Flashover Times in Small-Scale Fires Using Test Data", Fire and Materials, Vol. 1 (1976) p. 74.

22. Tourette, J. C., "L'influence des revetements sur le developpement de I'incendie Cah. Cent. Sci. Tech. Batin. No. 144, 1213 (1973).

23. Moulen, A. W., Grubits, S. J., Martin, K. G., and Dowling, V. P., "The Early Fire Behaviour of Combustible Wall Lining Materials," Fire and Materials, Vol. 4, No. 4, (1980) p. 165.

24. Spieth, H. H., Gaume, J. G., Luoto, R, E. and Klinck, D. M., "Investigate a Combined Hazard Index Methodology for Ranking an Aircraft Cabin Interior Material for Combustion Hazards", Part 1 - Final Report Draft, McDonnell Douglas Corporation (1981).

25. Tustin, E. A., "Development of Fire Test Methods for Airplane Interior Materials", Boeing Commercial Airplane Company, NASA CR-14568 (1979).

26. Allen, S., Nemeth, S. R., Peterson, J. M. and Tustin, E. A., "Airplane Interior Materials Fire Test Methodology", Boeing Commercial Airplane Co., Doc. No. D6-46952, Draft Report (March 1979).

27. Quintiere, J., "A Simplified Theory for Generalizing Results from a Radiant Panel Rate of Flame Spread Apparatus", Fire and Materials, Vol. 5, No. 2, (1981), p. 52. 
TABLE 1

COMPARISON OF ASTM E-162 WITH ROOM TEMPERATURE [11]

\begin{tabular}{|c|c|c|c|c|}
\hline Material & $\begin{array}{c}\text { ASTM E-162 } \\
\text { Is }_{S}\end{array}$ & $1 \mathrm{~kg}(<100 \mathrm{~kW})$ & $\begin{array}{l}\text { Maximum Room } \mathrm{Te} \\
\text { ignition source }\end{array}$ & $\begin{array}{l}\text { peratures }\left({ }^{\circ} \mathrm{C}\right) \\
175 \mathrm{~kW} \text { ignition source }\end{array}$ \\
\hline 1 & 2 & & 250 & 800 \\
\hline 2 & 7 & & --- & 250 \\
\hline 3 & 41 & & 150 & 800 \\
\hline 4 & 50 & & 200 & 470 \\
\hline 5 & 55 & & 200 & 900 \\
\hline 6 & 59 & & 200 & 900 \\
\hline
\end{tabular}


TABLE 2

COMPARISGN OF ASTM E-162 FOR CORRIDOR FIRE SPREAD [12]

\begin{tabular}{|c|c|c|c|}
\hline $\begin{array}{r}\text { ASTM E } \\
\text { Ceiling } \\
\end{array}$ & $\begin{array}{r}62\left(I_{S}\right) \\
\text { Floor } \\
\end{array}$ & $\begin{array}{l}\text { Values } \\
\text { Walls }\end{array}$ & Fire Spread Distance (m) \\
\hline 130 & 0 & 0 & 12.2 \\
\hline 90 & 220 & 0 & 6.1 \\
\hline 0 & 435 & 0 & 12.2 \\
\hline 0 & 0 & 35 & $\geq 19.5 *$ \\
\hline 0 & 0 & 27 & 3.7 \\
\hline 11 & 0 & 11 & $\geq 19.5$ \\
\hline 21 & 0 & 21 & 6.1 \\
\hline 3 & 0 & 3 & 2.4 \\
\hline 8 & 0 & 8 & $\geq 19.5$ \\
\hline
\end{tabular}

*Fuil length of corridor 
TABLE 3

CORRIDOR SPREAD COMPARED WITH EARLY VERSION OF BS 476 P'T 1 [16]

$\begin{array}{ccl}\text { Test No } & \text { Class } & \text { Full-scale results } \\ 3 & 1 & \text { Did not spread } \\ 2 & 2 & \text { Did not spread } \\ 5 & 3 & \text { Small spread } \\ 1 & 4 & \text { Spread to end in } 9 \mathrm{~min} . \\ 4 & 4 & \text { Spread to end in } 4 \mathrm{~min} .\end{array}$

TABLE 4

ROOM WALL LINING TESTS COMPARED TO BS 476 PT 1 CLASS [17]

$\begin{array}{cc}\text { Class } & \text { Flashover time } \\ 4 & \begin{array}{c}\text { min }: \\ 6: 45\end{array} \\ 3 & 8: 15 \\ 1 & 9: 30 \text { and } 12: 00 \\ \text { non combustible } & 23: 30 \\ \text { non combustible } & 8: 00\end{array}$


TABLE 5

CORRIDOR WALL AND CEILING SPREAD COMPARED WITH BS 476 PART 6 [19]

Material

Plasterboard

Expanded polystyrene

Expanded polystyrene

Hardboard
BS 476 pt $6(I)$

4.7

7.9

19.4

35.6
Corridor Spread

None

None

$6 \mathrm{~m}$ in $14 \mathrm{~min}$

Full length (13m) in $9 \mathrm{~min}$

TABLE 6

FLASHOVER TIME IN 1/3-SCALE COMPARTMENT COMPARED WITH C OF EPIRADIATEUR [21]

$\underline{C}$

Flashover time (nin)

0

16

0.40

13.21

0.68

12.3

1.85

9.65

2. 18

8.65

3.42

9.85

3.67

3.97

7.83

4.64

8.0

5.0

7.68

8.0

9.78

9.6

8.0

5.13 
TABLE 7

ENERGY RELEASED IN AIRCRAFT TESTS COMPARED TO LABORATORY TEST RESULTS [25]

\begin{tabular}{|c|c|c|c|c|c|c|c|c|}
\hline \multirow{3}{*}{ Material } & $\begin{array}{l}\text { FAR } \\
\text { Bunsen }\end{array}$ & \multicolumn{2}{|c|}{$\begin{array}{l}\text { ASTM } \\
\text { E-162 }\end{array}$} & \multicolumn{2}{|c|}{ OSU energy at $215 \mathrm{~s}$} & \multirow{2}{*}{$\begin{array}{l}\text { OSU energy } \\
\text { at } 300 \mathrm{~s} \\
2.5 \mathrm{~W} / \mathrm{cm}^{2}\end{array}$} & \multicolumn{2}{|c|}{ Fu11-scale Energy } \\
\hline & Burner & Q & $I_{s}$ & $2.5 \mathrm{~W} / \mathrm{cm}^{2}$ & $5 \mathrm{~W} / \mathrm{cm} 2$ & & $a t 215 s^{*}$ & at $300 \mathrm{~s} * *$ \\
\hline & $\mathrm{cln}$ & - & - & $\mathrm{J} / \mathrm{cm}^{2}$ & $\mathrm{~J} / \mathrm{cm}^{2}$ & $\mathrm{~J} / \mathrm{cm}^{2}$ & $\mathrm{MJ}$ & MJ \\
\hline 412 & 8.47 & 4.82 & 23.9 & 1055 & 1986 & 1600 & 4.85 & 0.93 \\
\hline N02 & 10.24 & 10.75 & 346 & 647 & 647 & 568 & 4.54 & 5.75 \\
\hline 416 & 11.85 & 3.02 & 28.1 & 420 & 471 & 442 & 2.00 & 2.11 \\
\hline 402 & 9.91 & 1.88 & 49.6 & 250 & 698 & 248 & 1.79 & 1.74 \\
\hline
\end{tabular}

\footnotetext{
* Post crash fire simulation

** Infilight fire simulation
} 


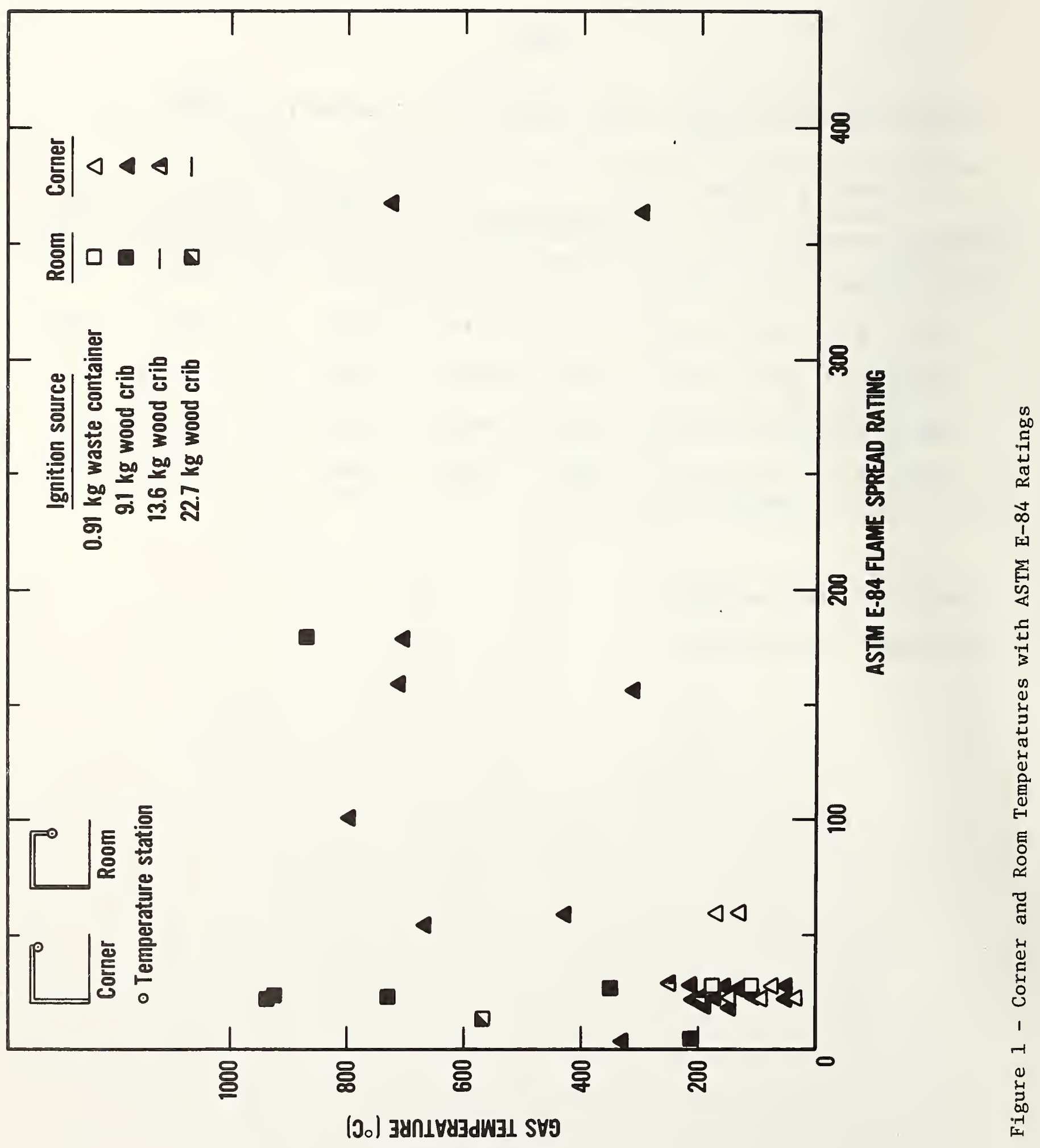




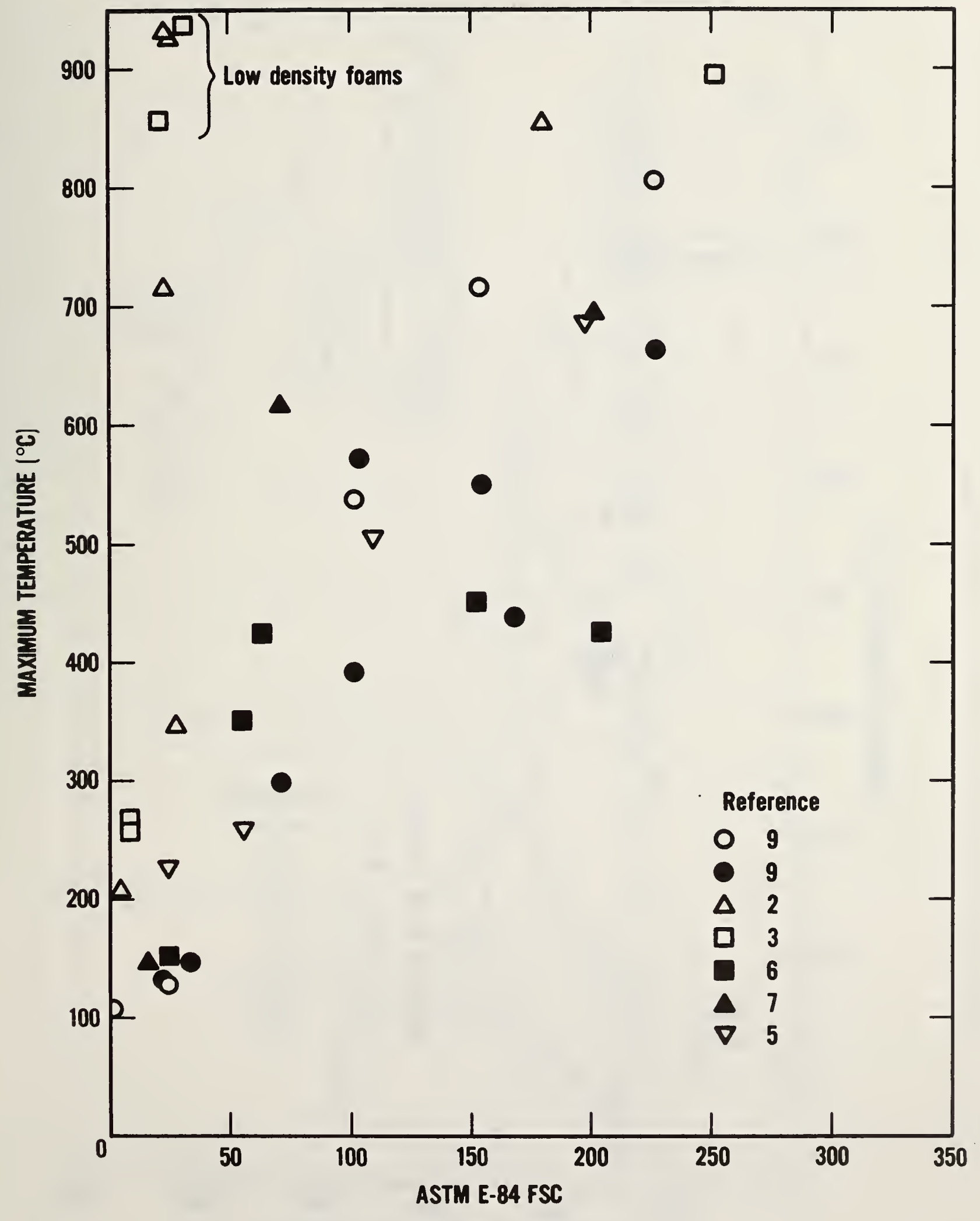

Figure 2 - Maximum Room Temperatures with ASTM E-84 


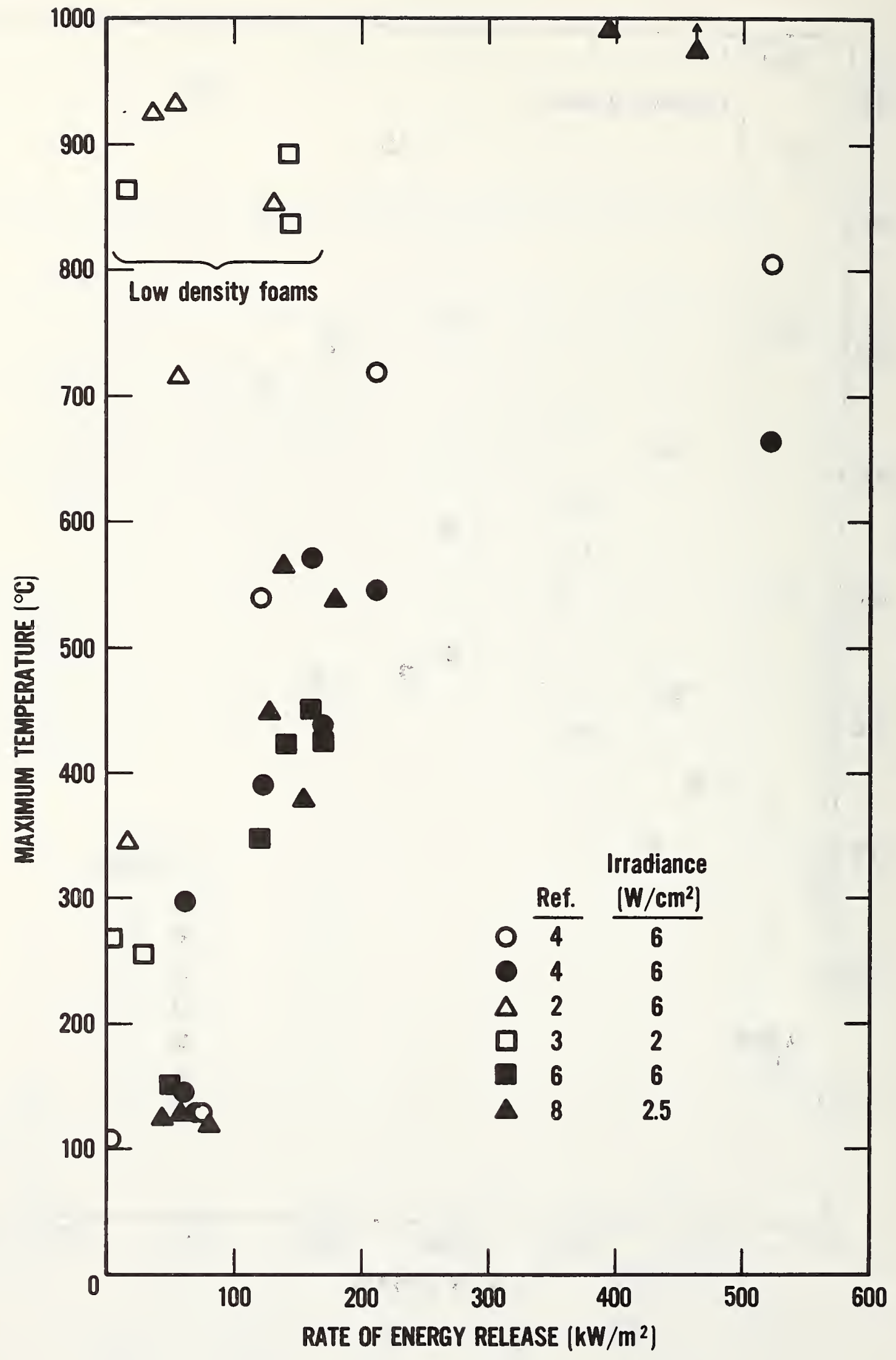

Figure 3 - Maximum Room Temperatures with Energy Release Data 


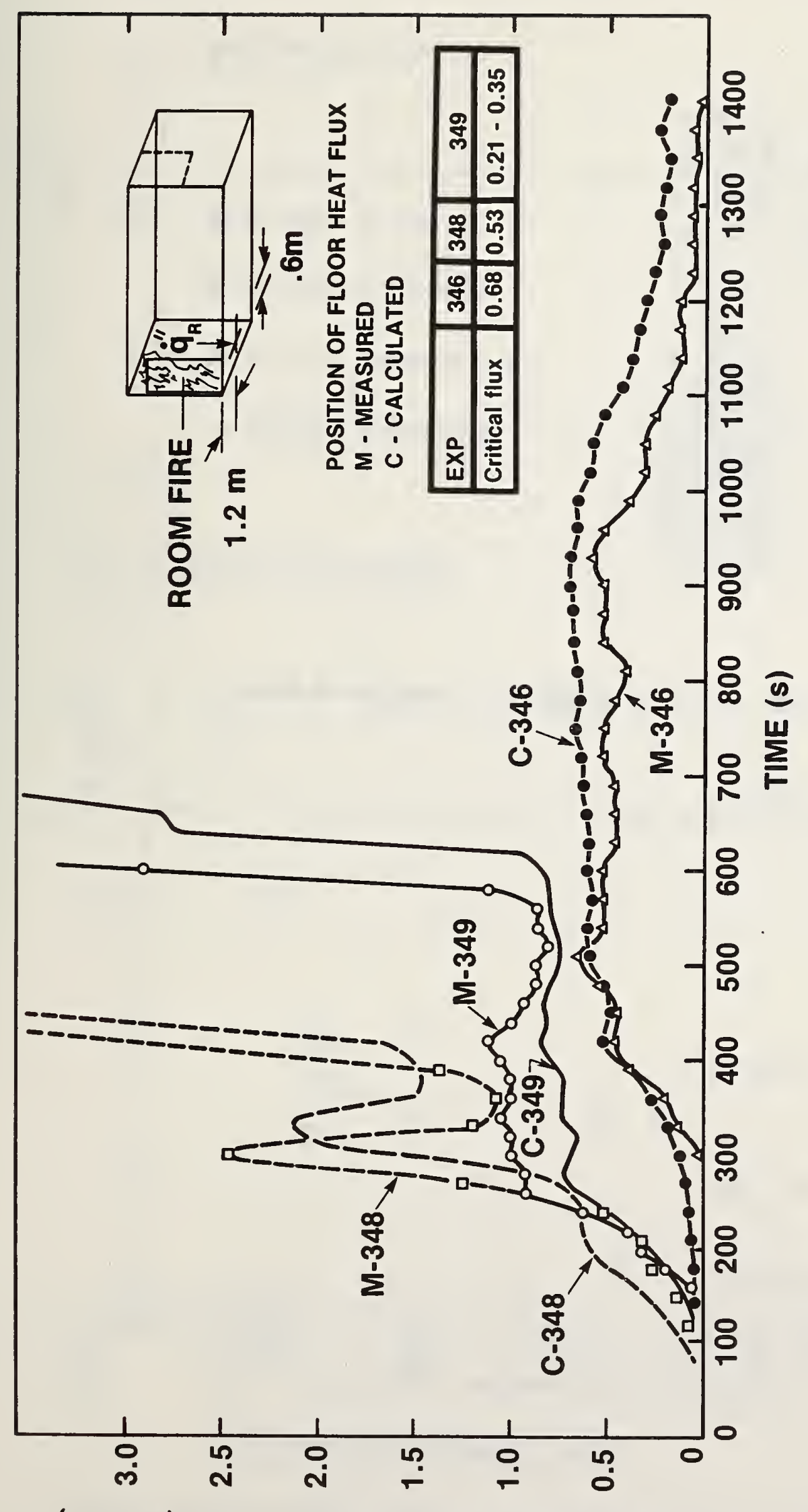

ปn

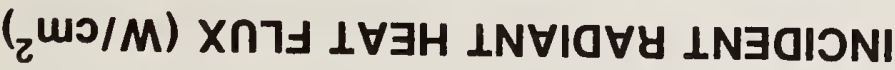




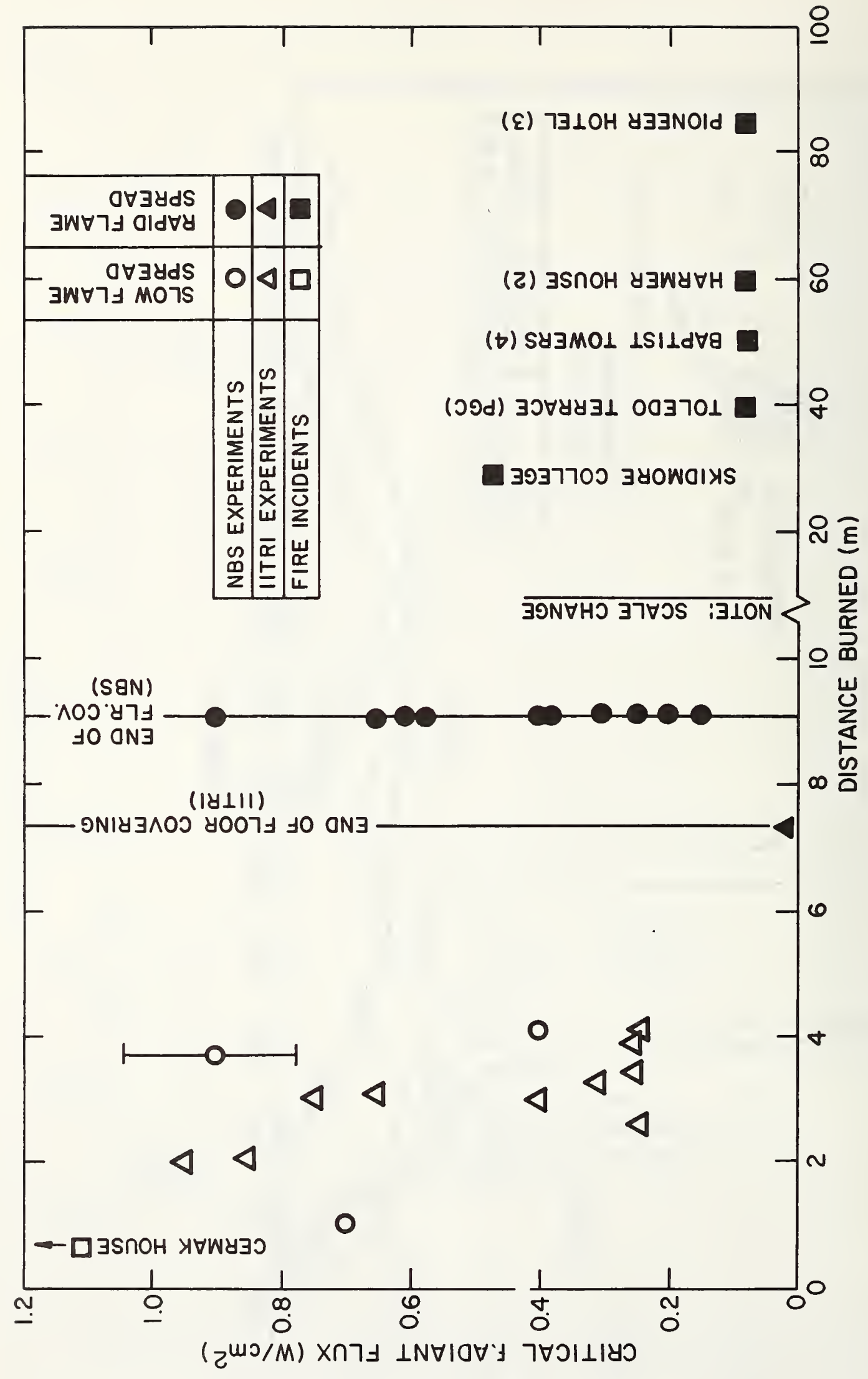

Figure 5 - Critical F1ux for Spread with Actual Fire Spread on Floors [13] 


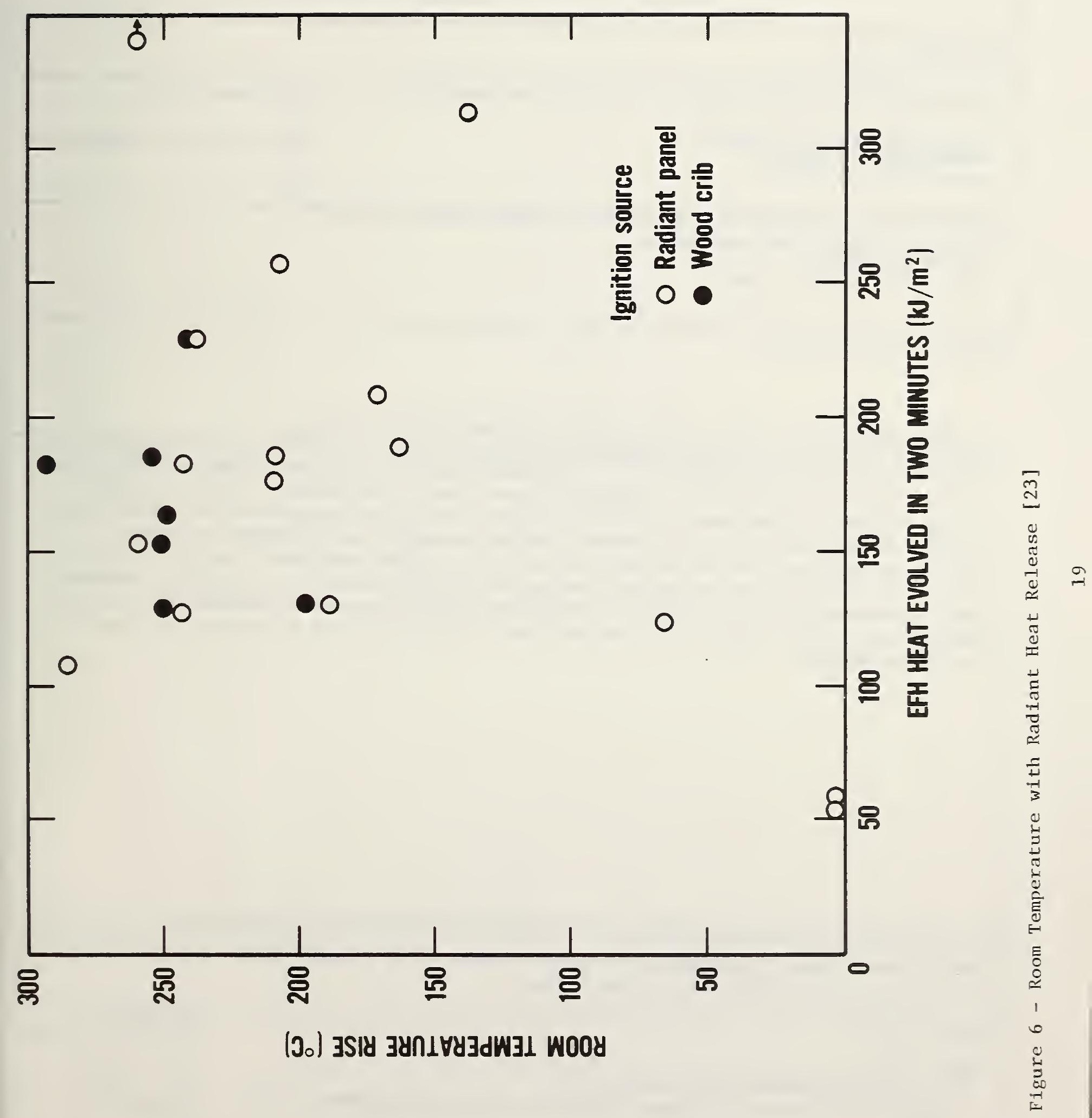


BIBLIOGRAPHIC DATA

1. PUBLICATION OR REPORT NO.

SHEET (See instructions)

4. TITLE AND SUBTITLE

An Assessment of Correlations Between Laboratory and Full-Scale Experiments for the FAA Aircraft Fire Safety Program, Part 4: Flammability Tests

5. AUTHOR(S)

J. G. Quintiere

6. PERFORMING ORGANIZATION (If joint or other than NBS, see instructions)

7. Contract/Grant No.

NATIONAL BUREAU OF STANDARDS

DEPARTMENT OF COMMERCE

WASHINGTON, D.C. 20234

8. Type of Report \& Period Covered

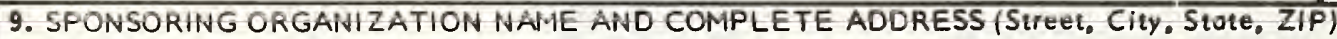

Federal Aviation Administration

Technical Center

Atlantic City, N.J. 08405

10. SUPPLEMENTARY NOTES

Document describes a computer program; SF-185, FIPS Software Summary, is attached.

11. ABSTRACT (A 200-word or less factual summary of most significant information. If document includes a significant bibliography or literature survey, mention it here) A review is made of studies in which full-scale fire growth was compared with laboratory test data on materials. Both room and corridor fires are included in which primarily interior lining materials have been the combustible element. The studies include standard test methods and other laboratory devices used in the United States and other countries. An effort was made to intercompare experimental results in a common basis. For example, maximum room temperature data are compared with ASTM E-84 flame spread classifications for several full-scale tests which involved nearly the same room geometries and same fuel arrangements.

12. KEY WORDS (Six to twelve entries; alphabetical order; copitalize only proper names; and separate key words by semicolons) Compartment fires; correlations; corridor tests; fire growth; fire tests; flammability; flashover; interior finishes; room fires.

13. AVAILABILITY

XX] Unlimited

$\square$ For Official Distribution. Do Not Release to NTIS

Order From Superintendent of Documents, U.S. Government Printing Office, Washington, D.C. 20402.
14. NO. OF PRINTED PAGES

27

15. Price

$\$ 7.50$ 

